\title{
CHANGES IN BITTERNESS, ANTIOXIDANT ACTIVITY AND TOTAL PHENOLIC CONTENT OF GRAPEFRUIT JUICE FERMENTED BY LACTOBACILLUS AND BIFIDOBACTERIUM STRAINS
}

\author{
A.M. Tran ${ }^{\mathrm{a}, \mathrm{b}}$, T.B. NGUYEN ${ }^{\mathrm{a}}$, V.D. NGUYeN ${ }^{\mathrm{b}}$, E. BUJNa ${ }^{\mathrm{a}}$, M.S. DAm ${ }^{\mathrm{b}}$ and Q.D. NGUYEN ${ }^{\mathrm{a}, *}$ \\ ${ }^{a}$ Research Centre for Bioengineering and Process Engineering, Faculty of Food Science, Szent István University; \\ H-1118 Budapest, Ménesi út 45. Hungary \\ ${ }^{\mathrm{b}}$ Institute of Biotechnology and Food Technology, Industrial University of Ho Chi Minh City, No. 12, Nguyen Van \\ Bao, Ward 4, Go Vap District, Ho Chi Minh City. Vietnam \\ (Received: 12 August 2019; accepted: 17 October 2019)
}

Four strains of Lactobacillus and Bifidobacterium including L. plantarum 01, L. fermentum D13, L. rhamnosus B01725, and B. bifidum B7.5 exhibiting naringinase production were applied in grapefruit juice fermentation. All investigated strains grew well in grapefruit juice without nutrition supplementation. In all cases, cell counts were $10^{8}-10^{9} \mathrm{CFU} \mathrm{ml}^{-1}$ after 24 hours of fermentation. The highest lactic acid and acetic acid productions were observed in the case of strain L. plantarum 01. The L. plantarum 01 and L. fermentum D13 strains prefer glucose over fructose and sucrose, whereas fructose was the most favoured sugar for L. rhamnosus B01725 and B. bifidum B7.5. At the end of the fermentation process, antioxidant activity and total polyphenol content of grapefruit juice decreased in all cases, but the changes were not significant. Significant decrease of naringin was observed in the case of L. plantarum $01,28 \%$ naringin in grapefruit juice was removed after fermentation. This result is promising for development of technology for production of probiotic grapefruit juice.

Keywords: grapefruit juice, naringin, bitterness, lactic acid fermentation, Lactobacillus, Bifidobacterium

Nowadays, fruit juice is consumed frequently worldwide because of its freshness and health promoting effects. Citrus family fruits such as grapefruit, orange, lemon, tangerine, etc. are rich in bioactive compounds such as minerals, vitamins, fibres, and antioxidants (ZHANG, 2007). Unfortunately, bitterness makes these fruit juices undesirable and unacceptable by consumers (RIBEIRO \& RIBEIRO, 2008).

Bitterness in citrus fruits is primarily related to two compounds - naringin and limonin, and naringin is the main bitter component. Grapefruit juices contain more than $300-400 \mu \mathrm{g} \mathrm{ml}^{-1}$ naringin (SOARES \& HoTCHKISS, 1998). Some techniques have been reported for debittering, including adsorption technique (KoLA et al., 2010) or use of $\beta$-cyclodextrin (MoNGKOLKUL et al., 2006). These methods have some drawbacks affecting juice acidity, flavour, sweetness, and turbidity as well as low efficiency (RIBEIRO \& RIBEIRO, 2008). The application of enzyme in reduction of naringin concentration is a promising technique, because it improves the quality of citrus juices while maintaining health properties.

Naringinase is an enzyme complex consisting of $\alpha$-L-rhamnosidase (EC.3.2.1.40) and $\beta$-D-glucosidase (EC.3.2.1.21). While $\alpha$-L-rhamnosidase hydrolyses naringin to prunin and rhamnose, $\beta$-D-glucosidase hydrolyses prunin into non-bitter naringenin and glucose. These products have great potential, especially in food and pharmaceutical industries (PURI, 2012). Production of naringinase from fungi has been well documented (CHEN et al., 2013; ZHU et al., 2017), although very few studies are found in the literature regarding naringinase activity

\footnotetext{
* To whom correspondence should be addressed.

Phone: +36 1305 7640; fax:+36 1305 7558; e-mail: nguyen.duc.quang@etk.szie.hu
}

0139-3006 C 2020 The Authors 
from bacteria. Despite some studies on bacterial naringinase, especially naringinase from probiotic bacteria were published (AvILA et al., 2009; BEEKWILDER et al., 2009; ZHANG et al., 2015), the debittering capacity of these bacteria is still less understood. In this study, naringinase from probiotics as well as simultaneous debittering and fermentation of grapefruit juice were studied.

\subsection{Materials and methods}

\subsection{Grapefruit juice}

The $100 \%$ grapefruit juice was purchased from the local market. The initial $\mathrm{pH}$ of the juice was adjusted to $\mathrm{pH} 6.3$ with $4 \mathrm{~N} \mathrm{NaOH}$ before fermentation.

\subsection{Strains and cultures}

Bacteria (Lactobacillus plantarum 01, Lactobacillus rhamnosus B01725, Lactobacillus fermentum D13, and Bifidobacterium B7.5) were from the strain collection of the Department of Brewing and Distilling, Szent István University, Budapest, Hungary.

All strains of Lactobacillus were cultured in MRS medium at $37^{\circ} \mathrm{C}$ for $24 \mathrm{~h}$. B. bifidum B7.5 was cultivated in TPY medium at $37^{\circ} \mathrm{C}$ for $24 \mathrm{~h}$ under anaerobic conditions (in Bugbox anaerobic chamber, Ruskin Technology, USA).

\subsection{Fermentation of grapefruit juice}

Grapefruit juice in $100 \mathrm{ml}$ flask was inoculated with bacteria cultures and kept under aerobic conditions (in the case of lactobacilli) or anaerobic conditions (in the case of B. bifidum B7.5) at $37^{\circ} \mathrm{C}$ for 24 hours. Samples were taken at given time intervals and analysed. TPY and MRS agar media were used to determine the cell number of bifidobacteria and lactobacilli, respectively (Bujna et al., 2018).

\subsection{Analysis of carbohydrates and organic acids}

The samples of fermented grapefruit juice were centrifuged at 14000 r.p.m. for $10 \mathrm{~min}$. The cell-free supernatant of grapefruit juice was used to determine the concentration of sugars and organic acids by HPLC method (BuJNA et al., 2018).

\subsection{Analysis of antioxidant capacity}

Ferric-reducing power (FRAP) assay was used to measure the total antioxidant capacity of the fermented grapefruit juices (NGUYEN et al., 2019).

\subsection{Analysis of total polyphenol content (TPC)}

Total phenolic content was determined using the method described previously (NGUYEN et al., 2019).

\subsection{Determination of naringin concentration}

Naringin in fermented grapefruit juices were evaluated by HPLC method (RIBEIRO and RiBeIRo, 2008). The Surveyor HPLC system (Thermal Scientific Corporation, USA) consisted of a quadruple pump, an autosampler, a photodiode array (PDA) detector, and a column of 
Supelcosil ${ }^{\mathrm{TM}}$ LC-18 $(250 \times 4.6 \mathrm{~mm})$ was applied. The mobile phase consisted of acetonitrile (A) and water (B). Separation was performed using a gradient program: 0-8 min 23\% A; 8-15 min 23-65\% A linear; 15-20 min 65-70\% A linear; 20-21 min 70-23\% A linear; 21-22 $\min 23 \% \mathrm{~A}$, and components were detected at $280 \mathrm{~nm}$. The standard solution of naringin $(0.1 \%)$ was prepared in a mixture of absolute ethanol:sodium acetate buffer $0.02 \mathrm{M}, \mathrm{pH} 4.0$ ( $1: 1$ ratio in volume). Both internal and external standards were prepared and injected.

\subsection{Statistical analysis}

All data were analysed by one-way ANOVA as well as unpaired and paired $t$-tests using Statistica v9.0 software package (StatSoft, USA). Generally, $\mathrm{P}<0.05$ was accepted as statistical significance level. The results were presented as mean and standard deviation (SD).

\section{Results and discussion}

\subsection{Changes of cell counts, $p H$, carbohydrates, and organic acids in grapefruit juice}

Grapefruit juice was inoculated with different strains of Lactobacillus and Bifidobacterium (L. plantarum 01, L. rhamnosus B01725, L. fermentum D13, and B. bifidum B7.5) with about $10^{6} \mathrm{CFU} \mathrm{ml}{ }^{-1}$ of initial cell concentration. The results are presented in Figure 1. All investigated lactic acid bacteria grew well in grapefruit juice without nutrition supplementation. After 24 $\mathrm{h}$ of fermentation, almost all strains reached cell counts of $10^{9} \mathrm{CFU} \mathrm{ml}^{-1}$ except $L$. rhamnosus B01725, where the population was $5.3 \times 10^{8} \mathrm{CFU} \mathrm{ml}^{-1}$. WANG and co-workers (2009) produced probiotic noni juice with lactic acid bacteria and bifidobacteria, and they reported that all $L$. casei, L. plantarum, B. longum strains reached about $1 \times 10^{9} \mathrm{CFU} \mathrm{ml}^{-1}$ after $48 \mathrm{~h}$ of fermentation at $30{ }^{\circ} \mathrm{C}$. In another study, L. rhamnosus was used to ferment carrot juice (NAZZARo et al., 2008). The cell count of $L$. rhamnosus was higher than our data in the case of $L$. rhamnosus B01725 (about $5 \times 10^{9} \mathrm{CFU} \mathrm{ml}^{-1}$ ). However, this cell count was reported after $48 \mathrm{~h}$ of fermentation at $37{ }^{\circ} \mathrm{C}$. Our results were significantly higher than those published by BuJNA and co-workers (2018), when apricot juice was fermented by mono and mixed cultures of probiotic Lactobacillus and Bifidobacterium strains; when carrot juice was fermented by Bifidobacterium strains (Kun et al., 2008), or in the case of mulberry (ZHENG et al., 2014).

During fermentation, short chain fatty acids were produced decreasing the $\mathrm{pH}$ values (Fig. 2), and at the end of the process, the final $\mathrm{pH}$ ranged from 4.4 to 4.7 . The reduction of $\mathrm{pH}$ during fermentation of probiotic products is of great importance for deciding the time of fermentation as well as maintaining the quality of product. Lactic acid and acetic acid were produced in the ranges of 9.6-186 $\mathrm{mM}$ and 8.9-1074 $\mathrm{mM}$, respectively (Table 1). These results were higher than those conducted by CHAMPAGNE and co-workers (2009), when they cultured mono and mixed starters of probiotic strains in milk and laboratory soy beverage. In the case of grapefruit juice fermented by Lactobacillus spp., greater acetic acid production was observed. The presence of citric acid in the grapefruit juice with the initial concentration of $123 \mathrm{mM}$ can explain the formation of acetic acid by Lactobacillus species through the citric cycle (Krebs cycle) leading to decreasing concentration of citric acid and increasing acetic acid content (Torino et al., 2005). Citric acid could not be detected in grapefruit juice after fermentation by Lactobacillus, while the amount of citric acid decreased by B. bifidum B7.5 fermentation (Table 1). Our results are in agreement with data reported by MousAVI and co-workers (2010), where the initial concentration of citric acid in pomegranate juice 
decreased significantly during the fermentation by lactic acid bacteria (L. plantarum, $L$. delbruekii, L. acidophilus, and L. paracasei). The production of organic acids in lactic fermentation in different media including fruit and vegetable juices could depend on the quality of media and strains (ZALÁN et al. 2009; HaVAS et al., 2014).

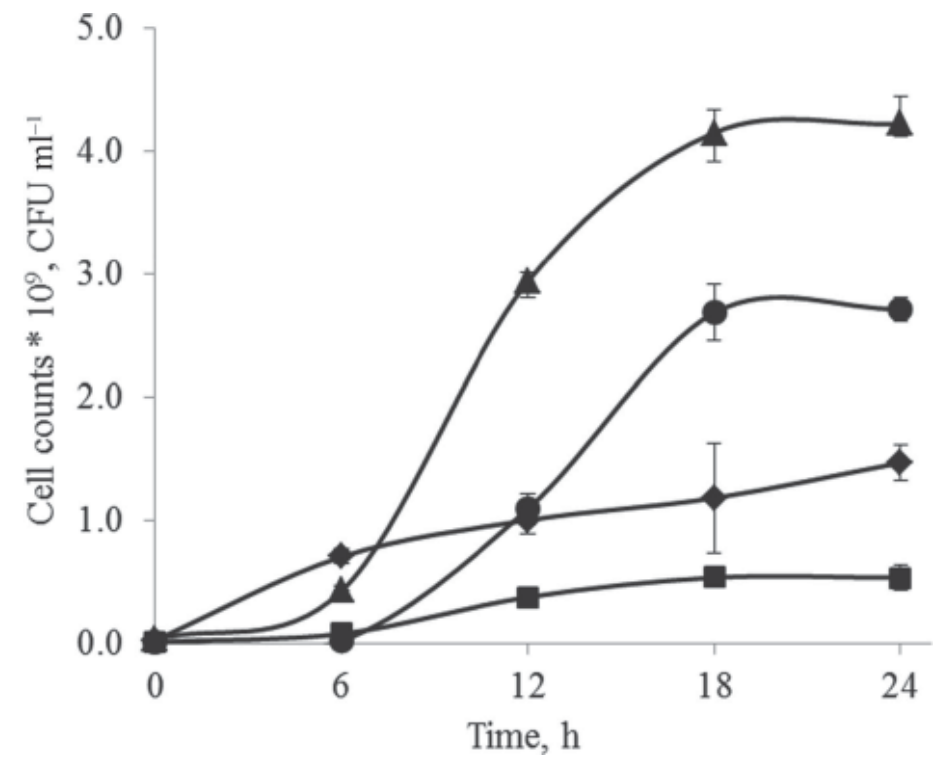

Fig. 1. Changes of microbial population in grapefruit juice during fermentation by B. bifidum B7.5 (•); L. plantarum 01 (४); L. rhamnosus B01725 (घ); and L. fermentum D13 ( $\mathbf{(})$

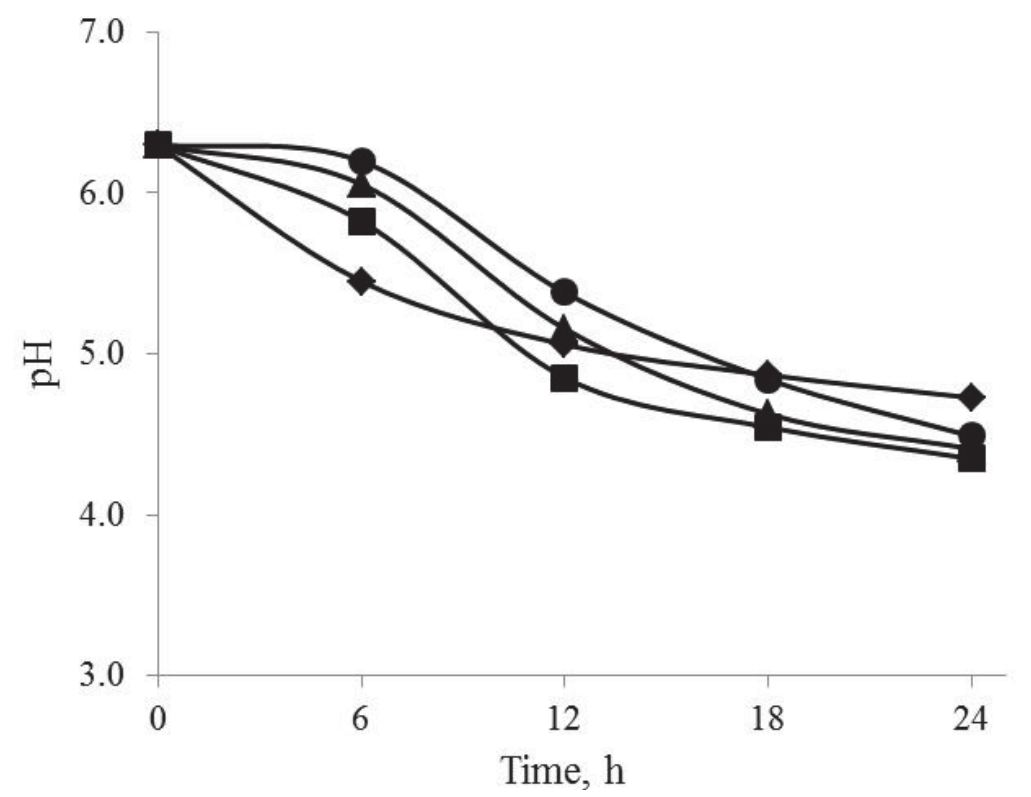

Fig. 2. Changes of $\mathrm{pH}$ of grapefruit juice during fermentation by B. bifidum B7.5 (•); L. plantarum $01(\bullet)$; L. rhamnosus B01725 (๘); and L. fermentum D13 (ム) 
Table 1. Organic acid concentrations of grapefruit juice after fermentation

\begin{tabular}{lccccc}
\hline Strain & Lactic acid & Acetic acid & Citric acid & Oxalic acid & Malic acid \\
\cline { 2 - 6 } & \multicolumn{5}{c}{ Concentration $(\mathrm{mM})$} \\
\hline $0 \mathrm{~h}$ & $2.17^{\mathrm{a}} \pm 0.42$ & $4.53^{\mathrm{a}} \pm 0.8$ & $123^{\mathrm{c}} \pm 5.3$ & $2.84 \pm 0.99$ & $0.09^{\mathrm{c}} \pm 0.002$ \\
L. plantarum 01 & $186^{\mathrm{c}} \pm 3.5$ & $1074^{\mathrm{c}} \pm 28$ & - & $10.7^{\mathrm{c}} \pm 0.32$ & $0.05^{\mathrm{c}} \pm 0.001$ \\
L. rhamnosus B01725 & $172^{\mathrm{c}} \pm 5.2$ & $645^{\mathrm{c}} \pm 30$ & - & $9.8^{\mathrm{b}} \pm 0.76$ & $0.04^{\mathrm{c}} \pm 0.001$ \\
L. fermentum D13 & $161^{\mathrm{c}} \pm 6.4$ & $539^{\mathrm{b}} \pm 51$ & - & $7.1^{\mathrm{c}} \pm 0.21$ & - \\
B. bifidum B7.5 & $9.6^{\mathrm{b}^{\mathrm{b}} \pm 0.82}$ & $8.9^{\mathrm{a}} \pm 1.6$ & $77.7^{\mathrm{c}} \pm 3.4$ & $3.8^{\mathrm{c}} \pm 0.11$ & $0.02^{\mathrm{b}} \pm 0.002$ \\
\hline
\end{tabular}

a: Significant at $80 \%$ level; ${ }^{\text {b}}$ : significant at $90 \%$ level; ${ }^{\text {c }}$ : significant at $95 \%$ level

During the fermentation of grapefruit juice, the concentration of sucrose decreased in all cases, and there was no significant difference of sucrose content after fermentation $(p<0.05)$ among strains (Table 2). The result of sucrose consumption was in agreement with the study of BUJNA and co-workers (2018), where they carried out lactic fermentation of apricot juice by mono and mixed cultures of probiotic Lactobacillus and Bifidobacterium strains. The contents of glucose and fructose were utilized at different rates. In general, the orders of sugars consumption were fructose $>$ glucose $>$ sucrose in cases of L. rhamnosus B01725 and B. bifidum B7.5, and glucose $>$ fructose $>$ sucrose in cases of $L$. plantarum 01 and $L$. fermentum D13 strains. The sugars can be fermented by probiotic bacteria via the EmbdenMeyerhof pathway (EMP) or the phosphoketolase pathway (PKP), leading to homolactic and heterolactic fermentation profiles, respectively.

Table 2. Concentration of carbohydrates in grapefruit juice after fermentation

\begin{tabular}{lccc}
\hline Strain & Sucrose & Glucose & Fructose \\
\cline { 2 - 4 } & & $(\mathrm{g} / 100 \mathrm{ml})$ & \\
\hline $0 \mathrm{~h}$ & $2.5^{\mathrm{c}} \pm 0.02$ & $3.6^{\mathrm{c}} \pm 0.03$ & $3.1^{\mathrm{c}} \pm 0.04$ \\
L. plantarum 01 & $2.01^{\mathrm{c}} \pm 0.03$ & $2.52^{\mathrm{c}} \pm 0.04$ & $2.61^{\mathrm{c}_{ \pm}} \pm 0.04$ \\
L. rhamnosus B01725 & $2.17^{\mathrm{b}} \pm 0.11$ & $3.01^{\mathrm{a}} \pm 0.16$ & $2.03^{\mathrm{b}} \pm 0.1$ \\
L. fermentum D13 & $2.07^{\mathrm{c}} \pm 0.02$ & $2.31^{\mathrm{b}} \pm 0.02$ & $2.7^{\mathrm{c}} \pm 0.02$ \\
B. bifidum B7.5 & $2.17^{\mathrm{a}} \pm 0.17$ & $2.8^{\mathrm{a}} \pm 0.21$ & $2.29^{\mathrm{a}} \pm 0.17$ \\
\hline
\end{tabular}

a: Significant at $90 \%$ level, ${ }^{\text {b }}$ : significant at $95 \%$ level, ${ }^{\text {c }}$ : significant at $99 \%$ level

\subsection{Changes of antioxidant capacity and total polyphenol content of grapefruit juice}

Fermented fruit juice is considered "functional food" because of bioactive compounds such as fibre, oligosaccharides, and bacteria that promote the equilibrium of intestinal bacterial strains (PERricone et al., 2015). The highest TPC and antioxidant activity were observed in juice fermented by B. bifidum B7.5 strain (Table 3). Significant reduction of antioxidant activity was observed in all other cases, especially when grapefruit juice was fermented by $L$. rhamnosus B01725 strain $(7.72 \mathrm{mM} \mathrm{FeSO}$ ). Due to anaerobic fermentation, fermented 
grapefruit juice did not get exposed to oxygen, leading to minimum decrease in TPC as well as antioxidant activity. An increase in antioxidant capacity was obtained in carrot juice fermented by L. bulgaricus and L. rhamnosus (NAZZARO et al., 2008), and in noni juice by B. longum, L. casei, and L. plantarum (WANG et al., 2009). It confirms that antioxidant activity varies with starter microorganism and cannot be affected synergistically (BUJNA et al., 2018).

Table 3. Changes of TPC and antioxidant capacity in fermented grapefruit juice

\begin{tabular}{lcc}
\hline Strains & $\begin{array}{c}\text { TPC } \\
\left(\mu \mathrm{g} \mathrm{ml}^{-1} \text { gallic acid }\right)\end{array}$ & $\begin{array}{c}\text { Antioxidant activity } \\
\left(\mathrm{mM} \mathrm{FeSO}_{4}\right)\end{array}$ \\
\hline 0 h & $1036^{\mathrm{b}} \pm 16$ & $8.57^{\mathrm{c}} \pm 0.09$ \\
L. plantarum 01 & $997^{\mathrm{b}} \pm 16$ & $7.9^{\mathrm{b}} \pm 0.27$ \\
L. rhamnosus B01725 & $1006^{\mathrm{b}} \pm 12$ & $7.72^{\mathrm{b}} \pm 0.25$ \\
L. fermentum D13 & $991^{\mathrm{b}} \pm 34$ & $8.05^{\mathrm{b}} \pm 0.25$ \\
B. bifidum B7.5 & $1029^{\mathrm{b}} \pm 20$ & $8.23^{\mathrm{b}} \pm 0.18$ \\
\hline
\end{tabular}

a: Significant at $90 \%$ level, ${ }^{\text {b}}:$ significant at $95 \%$ level, ${ }^{\text {c}}$ : significant at $99 \%$ level

\subsection{Change of naringin concentration}

The initial naringin content in the grapefruit juice was about $2.5 \mathrm{~g} \mathrm{l}^{-1}$. In all cases, the maximum decrease of naringin (about 28\%) was obtained after $24 \mathrm{~h}$ of fermentation by mono starter L. plantarum 01 strain (Fig. 3). This result can be explained by the plant-related origin of the L. plantarum species. In view of the frequent occurrence of lactobacilli on decaying plant material and fermented vegetable substrates, it is expected that their genomes carry one or more genes encoding enzymes capable of utilizing rhamnosilated compounds (BEEKWILDER et al., 2009).

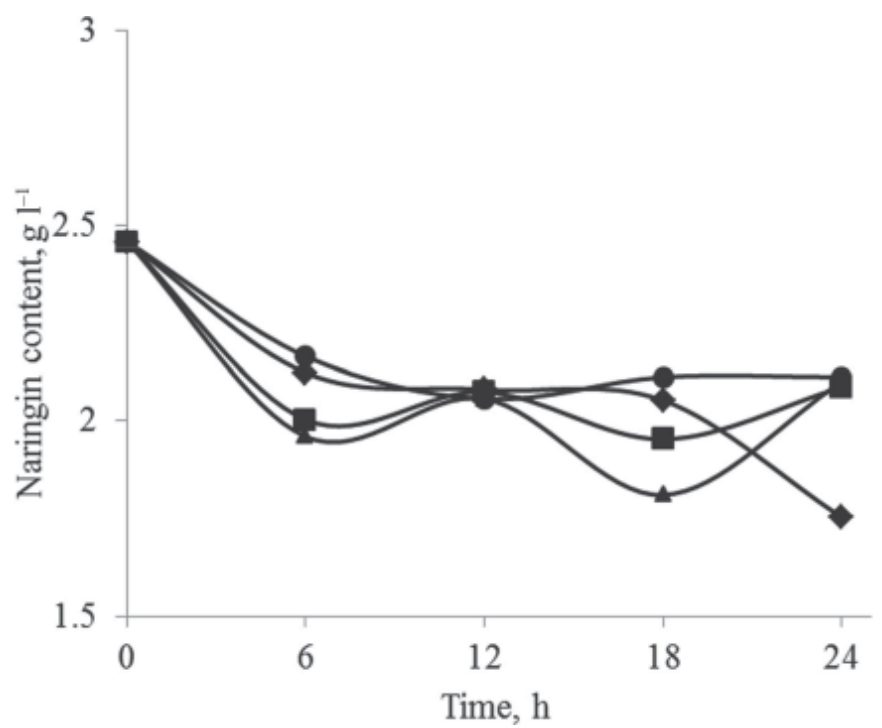

Fig. 3. Changes of naringin concentration of grapefruit juice during fermentation by B. bifidum B7.5 (•);

$$
\text { L. plantarum } 01 \text { ( ); L. rhamnosus B01725 (®); and L. fermentum D13 (४) }
$$


ZHU and co-workers (2017) purified naringinase from Aspergillus oryzae 1125 and used to debitter orange juice. The naringin concentration decreased to below $30 \mu \mathrm{g} \mathrm{ml}^{-1}$, meaning that the bitterness can be efficiently lowered by naringinase to below the threshold of taste. Naringinase from Cryptococcus albidus can reduce up to $84 \%$ naringin at $40{ }^{\circ} \mathrm{C}$ and $100 \%$ at $60{ }^{\circ} \mathrm{C}$ after $60 \mathrm{~min}$ of incubation (Borzova et al., 2018). PANDove and co-workers (2017) reported that the biotechnological potential of naringinase producing yeast, Clavispora lusitaniae, has been exploited for the processing of kinnow and lemon in the form of lowalcoholic naturally carbonated debittered fermented beverage. After three months of storage at refrigerated temperature, the naringin content in fermented kinnow-lemon beverage decreased from $443.2 \mathrm{ppm}$ to $176.4 \mathrm{ppm}$.

The efficiency of naringinase in our study is not as high as of other naringinase sources, however, it is the first report on simultaneous fermentation and reducing of naringin content in grapefruit juice.

\section{Conclusions}

Grapefruit juice can be used as substrate for growth of probiotic bacteria without any nutrient supplementation. All investigated Lactobacillus and Bifidobacterium strains have the ability to reduce naringin concentration, the main component causing the bitterness in grapefruit, while only minimal changes in the levels of antioxidants and TPC were observed. Our results are very promising and can form the basis of technology development for the production of less bitter probiotic citrus juices rich in nutrients.

This work is supported by the New Széchenyi Plant Project No. EFOP-3.6.3.-VEKOP-16-2017-00005 and by the Higher Education Institutional Excellence Program (20430-3/2018/FEKUTSTRAT) awarded by the Ministry of Human Capacities within the framework of plant breeding and plant protection researches of Szent István University, as well as a Bolyai Research Grant from the Hungarian Academy of Sciences.

\section{References}

Avila, M., Jaquet, M., Moine, D., Requena, T., Pelaez, C., Arigoni, F. \& Jankovic, I. (2009): Physiological and biochemical characterization of the two $\alpha$-L-rhamnosidases of Lactobacillus plantarum NCC245. Microbiology, 155, 2739-2749.

Beekwilder, J., Marcozzi, D., Vecchi, S., De Vos, R., Janssen, P., ... \& Hall, R.D. (2009): Characterization of rhamnosidases from Lactobacillus plantarum and Lactobacillus acidophilus. Appl. Environ. Microb., 75 , $3447-3454$

Borzova, N., Gudzenko, O. \& Varbanets, L. (2018): Purification and characterization of a naringinase from Cryptococcus albidus. Appl. Biochem. Biotech., 184, 953-969.

Bujna, E., Farkas, N.A., Tran, A.M., Dam, M.S. \& Nguyen, Q.D. (2018): Lactic acid fermentation of apricot juice by mono- and mixed cultures of probiotic Lactobacillus and Bifidobacterium strains. Food Sci. Biotechnol., 27, 547-554.

Champagne, C., Green-Johnson, J., Raymond, Y., Barrette, J. \& Buckley, N. (2009): Selection of probiotic bacteria for the fermentation of a soy beverage in combination with Streptococcus thermophilus. Food Res. Int., 42(5-6), 612-621.

Chen, Y., Ni, H., Chen, F., CAI, H., LI, L. \& Su, W. (2013): Purification and characterization of a naringinase from Aspergillus aculeatus JMUdb058. J. Agr. Food Chem., 61, 931-938.

Havas, P., Kun, Sz., Styevkó, G., Slačanac, V., Hardi, J. \& Rezessy-Szabó, J. (2014): Fruit and vegetable juice fermentation with bifidobacteria. Acta Alimentaria, 43 (Suppl.), 64-72. 
Kola, O., Kaya, C., Duran, H. \& Altan, A. (2010): Removal of limonin bitterness by treatment of ion exchange and adsorbent resins. Food Sci. Biotechnol., 19, 411-416.

Kun, S., Rezessy-Szabó, J.M., NGuYen, Q.D. \& HoschKe, Á. (2008): Changes of microbial population and some components in carrot juice during fermentation with selected Bifidobacterium strains. Process Biochem., 43, $816-821$.

Mongkolkul, P., Rodart, P., Pipatthitikorn, T., Meksut, L. \& Sa-Nguandeekul, R. (2006): Debittering of tangerine Citrus reticulata Blanco juice by $\beta$-cyclodextrin polymer. J. Incl. Phenom. Macro., 56(1-2), $167-$ 170.

Mousavi, Z.E., Mousavi, S.M., RaZavi, S.H., Eмam-Djomeh, Z. \& Kiani, H. (2010): Fermentation of pomegranate juice by probiotic lactic acid bacteria. World J. Microb. Biot., 27(1), 123-128.

Nazzaro, F., Fratianni, F., Sada, A. \& Orlando, P. (2008): Synbiotic potential of carrot juice supplemented with Lactobacillus spp. and inulin or fructooligosaccharides. J. Sci. Food Agr., 88(13), 2271-2276.

Nguyen, B.T., Bujna, E., Fekete, N., Tran, T.M.A., Rezessy-Szabo, J.M., Prasad, R. \& Nguyen, D.Q. (2019): Probiotic beverage from pineapple juice fermented with Lactobacillus and Bifidobacterium strains. Front. Nutr., 6, 54, 1-7.

Pandove, G., Sahota, P., Gupta, N. \& Singh, P. (2017): Biotechnological approach for production of fermented debittered blended beverage from Kinnow lemon using Clavispora lusitaniae. Vegetos, 30(Suppl), 69-75.

Perricone, M., Bevilacqua, A., Altieri, C., Sinigaglia, M. \& Corbo, M. (2015): Challenges for the production of probiotic fruit juices. Beverages, 1(2), 95-103.

PURI, M. (2012): Updates on naringinase: Structural and biotechnological aspects. Appl. Microbiol. Biot., 93(1), $49-60$.

RibeIRo, I.A. \& RibeIro, M.H.L. (2008): Naringin and naringenin determination and control in grapefruit juice by a validated HPLC method. Food Control, 19, 432-438.

SoAres, N. \& Hotchkiss, J. (1998): Bitterness reduction in grapefruit juice through active packaging. Packag. Technol. Sci., 11(1), 9-18.

Torino, M., Taranto, M. \& De Valdez, G.F. (2005): Citrate catabolism and production of acetate and succinate by Lactobacillus helveticus ATCC 15807. Appl. Microbiol. Biot., 69(1), 79-85.

Wang, C.Y., NG, C.C., Su, H., Tzeng, W.S. \& Shyu, Y.T. (2009): Probiotic potential of noni juice fermented with lactic acid bacteria and bifidobacteria. Int. J. Food Sci. Nutr., 60(6), 98-106.

Zalán, Z., Hudáček, J., Štětina, J., Chumchalová, J. \& Halász, A. (2009): Production of organic acids by Lactobacillus strains in three different media. Eur. Food Res. Technol., 230(3), 395-404.

ZHANG, J. (2007): Flavonoids in grapefruit and commercial grapefruit juices: concentration, distribution, and potential health benefits. Proc. Fl. S. Hortic. Soc., 120, 288-294.

Zhang, R., Zhang, B.L., XIE, T., LI, G.C., TuO, Y. \& XIANG, Y.T. (2015): Biotransformation of rutin to isoquercitrin using recombinant $\alpha$-L-rhamnosidase from Bifidobacterium breve. Biotechnol. Lett., 37, 1257-1264.

Zheng, X., Yu, Y., XIAO, G., Xu, Y., Wu, J., ... \& ZHANG, Y. (2014): Changes of anti-glucosidase content and some other characteristics in mulberry juice during fermentation with Leuconostoc mesenteroides. Acta Alimentaria, 43, 668-675.

ZhU, Y., JIA, H., XI, M., LI, J., YANG, L. \& LI, X. (2017): Characterization of a naringinase from Aspergillus oryzae 11250 and its application in the debitterization of orange juice. Process Biochem., 62, 114-121.

Open Access statement. This is an open-access article distributed under the terms of the Creative Commons Attribution 4.0 International License (https://creativecommons.org/licenses/by/4.0/), which permits unrestricted use, distribution, and reproduction in any medium, provided the original author and source are credited, a link to the CC License is provided, and changes - if any - are indicated. (SID_1) 